\title{
Marine Natural Occurring 2,5-Diketopiperazines: Isolation, Synthesis and Optical Properties
}

\author{
Laville Remi ${ }^{1}$, Thanh Binh Nguyen ${ }^{1}$, Moriou Celine 1, Petek Sylvain 2, Debitus Cecile ${ }^{2}$, \\ Al-Mourabit Ali ${ }^{1,}{ }^{*}$
}

${ }^{1}$ CNRS, Inst Chim Subst Nat, Ctr Rech Gif Sur Yvette, F-91198 Gif Sur Yvette, France.

${ }^{2}$ Ctr Polynesie Francaise, IRD, UMR241, Papeete, France.

* Corresponding author : Ali Al-Mourabit, email address : ali.al-mourabit@icsn.cnrs-gif.fr

\begin{abstract}
:
Seven 2,5-diketopiperazines (DKPs) were isolated from the Fijian marine sponge Acanthella cavernosa. NMR and circular dichroism (CD) comparison with synthetic L-L DKPs allowed us to determine unambiguously the $L-L$ absolute configuration of the natural DKPs. This work initiated the setting up of an optical properties database of natural DKPs, including specific rotation and CD.
\end{abstract}

Keywords : Diketopiperazine, Sponge, Marine Metabolite, Circular Dichroism 
2,5-Diketopiperazines (DKPs) are cyclic secondary metabolites directly resulted from the primary peptidic metabolites. They have been detected in beverages, foods and microorganisms. ${ }^{1}$ As the smallest cyclic peptides, DKPs provide interesting biological properties such as organoleptical, antitumoral, antifungal, antibacterial, antifouling and antiviral activities. ${ }^{2}$ Many natural metabolites including alkaloids are biosynthetically derived from diketopiperazines by oxidation and rearrangement reactions. ${ }^{3}$ They represent an interesting tool for medicinal chemistry since their heterocyclic cores provide a good template for further chemical and stereochemical modification. ${ }^{4}$ Proline (Pro) and arginine (Arg) units are usually found in biologically active DKPs. ${ }^{2 e, f, 3}$ Despite the increasing interest of DKPs, their stereochemical information was not well documented. DKP derivatives have attracted significant attention because of their potential rule as important class of multifunctional biomolecules. ${ }^{5}$ Their putative roles as signaling molecules in the chemical ecology context is more and more considered. ${ }^{6}$ Thus, determination of absolute configuration of cyclic dipeptides is of significant importance. ${ }^{7}$

As a part of our on-going research on bioactive natural compounds from Pacific Axinellidae marine sponges, a scrutinized study of secondary metabolites of a Fijian sample of the marine sponge Acanthella 
cavernosa led to the isolation of seven stereochemically unknown DKPs as minor compounds along with a known diterpenoid kalihinol Y. ${ }^{8}$ The lack of DKPs absolute configuration data in the literature along with small amounts of the DKPs isolated from natural sources, hamper the structural elucidation of such molecules.

In this paper, we describe the isolation and structural determination including absolute configuration of the isolated DKPs using a comparative of NMR and CD study with the corresponding synthesized DKPs.

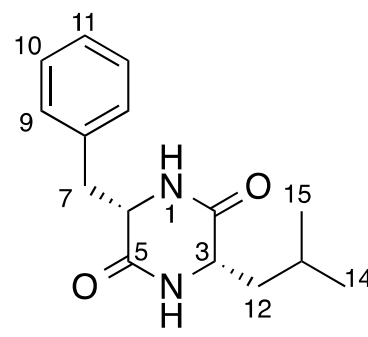

1

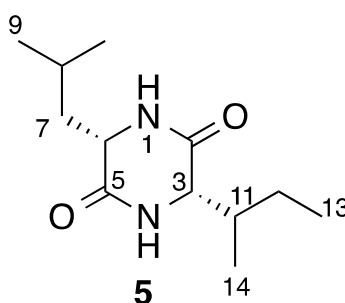

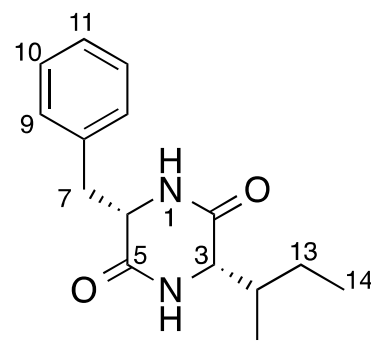

2

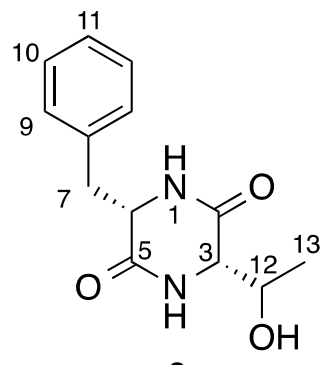

6

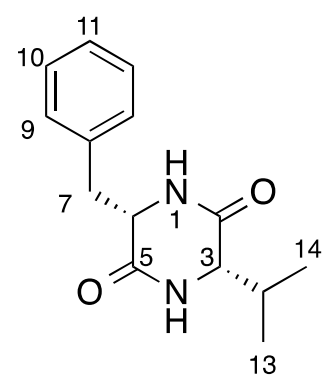

3

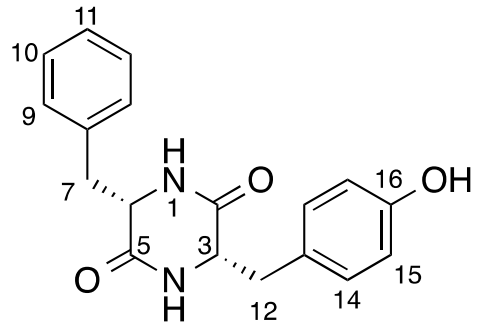

7

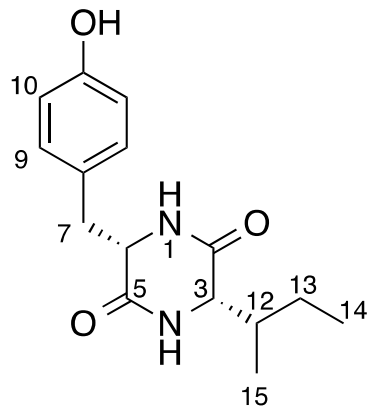

4

Figure 1

Isolation and structural elucidation. The lyophilised powder of Fijian marine sponge Acanthella cavernosa was first extracted with $\mathrm{CH}_{2} \mathrm{Cl}_{2}$ and then with $\mathrm{MeOH}$. The $\mathrm{MeOH}$ crude extract fraction was then subjected to a liquid-liquid partitioning between $\mathrm{H}_{2} \mathrm{O}$ and $n-\mathrm{BuOH}$. The obtained $n-\mathrm{BuOH}$ crude extract was fractionated by reversed phase flash chromatography using a decreasing polarity gradient of $\mathrm{H}_{2} \mathrm{O} / \mathrm{MeOH}, 1 / 0$ to $0 / 1$, then $\mathrm{MeOH} / \mathrm{CH}_{2} \mathrm{Cl}_{2}, 1 / 0$ to $0 / 1$. Repetitive fractionation on reversed phase preparative HPLC of the fraction eluated with $\mathrm{H}_{2} \mathrm{O} / \mathrm{MeOH}: 3 / 1$ gave the cyclo(L-Phe-L-Leu) (1), ${ }^{9}$ cyclo(L-Phe-L-Ile) (2), ${ }^{10}$ cyclo(L-Phe-L-Val) (3), ${ }^{10,11}$ cyclo(L-Tyr-L-Ile) (4), ${ }^{12}$ and cyclo(L-Leu-L-Ile) (5). ${ }^{13}$ Further HPLC studies of the polar $\mathrm{H}_{2} \mathrm{O}$ fraction led to the isolation with two DKPs: cyclo(L-Phe-L-Thr) (6) and cyclo (L-Phe-L-Tyr) $(7)^{8}$ along with other knouwn compounds (deoxycytidin, cytosine, deoxynebularine, deoxyinosine, tryptamine, phenylethylamine and 2-(4-hydroxyphenyl)ethylamine. 
Cyclo(L-Phe-L-Leu) (1) was isolated as a white solid and presented a molecular formula of $\mathrm{C}_{15} \mathrm{H}_{20} \mathrm{~N}_{2} \mathrm{O}_{2}$ ( $m / z 283.1412$ calcd for $\left.\mathrm{C}_{15} \mathrm{H}_{20} \mathrm{~N}_{2} \mathrm{O}_{2} \mathrm{Na}, 283.1422, \Delta-3.7 \mathrm{ppm}\right)$. The ${ }^{1} \mathrm{H}$ NMR spectrum (Table 1) showed characteristic signals for a phenyl moiety at $\delta_{\mathrm{H}} 7.30(2 \mathrm{H}, \mathrm{t}, J=6.9 \mathrm{~Hz}, \mathrm{H}-10), 7.26(1 \mathrm{H}, \mathrm{t}, J=6.9 \mathrm{~Hz}, \mathrm{H}-11)$ and $7.20(2 \mathrm{H}, \mathrm{d}, J=6.9 \mathrm{~Hz}, \mathrm{H}-9) \mathrm{ppm}$. The broad triplet at $\delta_{\mathrm{H}} 4.31 \mathrm{ppm}$ and the double doublet at $\delta_{\mathrm{H}} 3.66$ ppm were consistent with the usual diketopiperazine $\alpha \mathrm{CH}$. According to the molecular formula, phenylalanine (Phe) and leucine (Leu) or isoleucine (Ile) units were expected. The two doublets at $\delta_{\mathrm{H}} 0.73$ $(3 \mathrm{H}, \mathrm{d}, J=6.4 \mathrm{~Hz}, \mathrm{H}-14)$ and $0.69(3 \mathrm{H}, \mathrm{d}, J=6.4 \mathrm{~Hz}, \mathrm{H}-15) \mathrm{ppm}$ confirmed the presence of a Leu unit. The low chemical shifts of the protons H-12 can be explained by the shielding effect of the phenyl of Phe unit. This observation led us to conclude a cis relative configuration of H-3 and H-6. The specific rotation (Table 2) of $\mathbf{1}[\alpha]^{25}+11(\mathrm{c} 0.3, \mathrm{AcOH})$. Configurational considerations will be studied later.

Cyclo(L-Phe-L-Ile) (2) was isolated as a white solid and exhibited the same molecular formula as $\mathbf{1}$ $\left(\mathrm{C}_{15} \mathrm{H}_{20} \mathrm{~N}_{2} \mathrm{O}_{2}, m / z 283.1418\right.$ calcd for $\left.\mathrm{C}_{15} \mathrm{H}_{20} \mathrm{~N}_{2} \mathrm{O}_{2} \mathrm{Na}, 283.1422, \Delta-1.4 \mathrm{ppm}\right)$. The characteristic signals of the phenyl group and the DKP $\alpha \mathrm{CH}$ were still present. 2 was assigned as the cyclo(Phe-Ile) which is confirmed by the methyl groups at $\delta_{\mathrm{H}} 0.73(3 \mathrm{H}, \mathrm{d}, J=7.0 \mathrm{~Hz}, \mathrm{H}-15)$ and $0.68(3 \mathrm{H}, \mathrm{t}, J=6.6 \mathrm{~Hz}, \mathrm{H}-14) \mathrm{ppm}$. The shielded values of the isoleucine aliphatic chain are consistent with H-3 and H- 6 cis-configuration. The specific rotation recorded was not significant to conclude on the absolute configurations of 2 (vide infra). Cyclo(L-Phe-L-Val) (3) was isolated as a white solid with a molecular formula, $\mathrm{C}_{14} \mathrm{H}_{18} \mathrm{~N}_{2} \mathrm{O}_{2}$ calculated from the HRMS $m / z 269.1257$ calcd for $\mathrm{C}_{14} \mathrm{H}_{18} \mathrm{~N}_{2} \mathrm{O}_{2} \mathrm{Na}, 269.1266, \Delta-3.3 \mathrm{ppm}$. ${ }^{1} \mathrm{H}$ NMR spectrum showed the same signals corresponding to a DKP with a Phe unit. According to its molecular formula, 3 had one methylene less than 1 and 2 . As suggested by the methine at $\delta_{\mathrm{H}} 1.60(1 \mathrm{H}, \mathrm{m}, \mathrm{H}-12)$ ppm and the methyls at $\delta_{\mathrm{H}} 0.79(3 \mathrm{H}, \mathrm{d}, J=7.1 \mathrm{~Hz}, \mathrm{H}-13)$ and $0.42(3 \mathrm{H}, \mathrm{d}, J=6.9 \mathrm{~Hz}, \mathrm{H}-14) \mathrm{ppm}$, the missing unit is a Valine (Val). As for compounds $\mathbf{1}$ and $\mathbf{2}$, the Val isopropylic chain is affected by the Phe aromatic ring $(0.42 \mathrm{ppm}, 3 \mathrm{H}, \mathrm{d}$, $J=6.9 \mathrm{~Hz}, \mathrm{H}-14$ ), which is in accordance with the same relative configuration as the previous DKPs. The measured specific rotation, $[\alpha]_{\mathrm{D}}^{25}-5(\mathrm{c} 1.0, \mathrm{AcOH})$, was not similar to the published one (vide infra), thus, at this stage, we could not conclude on the absolute configuration.

Cyclo(L-Tyr-L-Ile) (4) which was isolated as a white solid presented a molecular formula of $\mathrm{C}_{15} \mathrm{H}_{20} \mathrm{~N}_{2} \mathrm{O}_{3}$ $\left(m / z 299.1362\right.$ calcd for $\mathrm{C}_{15} \mathrm{H}_{20} \mathrm{~N}_{2} \mathrm{O}_{3} \mathrm{Na}, 299.1372, \Delta-3.2 \mathrm{ppm}$. The ${ }^{1} \mathrm{H}$ NMR signals at $\delta_{\mathrm{H}} 7.02(2 \mathrm{H}, \mathrm{t}, J=$ $8.3 \mathrm{~Hz}, \mathrm{H}-9)$ and $6.69(2 \mathrm{H}, \mathrm{d}, J=8.5 \mathrm{~Hz}, \mathrm{H}-10)$ ppm corresponded to the phenol moiety of a Tyrosine (Tyr). The protons at $\delta_{\mathrm{H}} 1.42(1 \mathrm{H}, \mathrm{m}, \mathrm{H}-12), 0.81(1 \mathrm{H}, \mathrm{m}, \mathrm{H}-13), 0.76(3 \mathrm{H}, \mathrm{d}, J=7.0 \mathrm{~Hz}, \mathrm{H}-15), 0.71(3 \mathrm{H}, \mathrm{t}, J=$ $6.9 \mathrm{~Hz}, \mathrm{H}-14)$ and $0.66(1 \mathrm{H}, \mathrm{m}, \mathrm{H}-13)$ ppm were similar to those of the Ile unit of 2 . H-3 and H-6 relative configuration of $\mathbf{4}$ was cis according to the shielded chemical shifts of Ile due to the Tyr aromatic ring. This DKP is described here for the first time and was only detected by LCMS in a weed in $2008 .{ }^{12 a}$ For absolute configuration see below. 
Cyclo(L-Leu-L-Ile) (5) was isolated as a white solid and presented a molecular formula of $\mathrm{C}_{12} \mathrm{H}_{22} \mathrm{~N}_{2} \mathrm{O}_{2}$ ( $m / z 263.1728$ calcd for $\mathrm{C}_{13} \mathrm{H}_{24} \mathrm{~N}_{2} \mathrm{O}_{2} \mathrm{Na}, 263.1735, \Delta-2.6 \mathrm{ppm}$ ).

Table 1. Comparative ${ }^{1} \mathrm{H}$ NMR Spectroscopic Data (500 MHz, MeOD) for DKPs 1-7

\begin{tabular}{|c|c|c|c|c|c|c|c|}
\hline DKP & 1 & 2 & 3 & 4 & 5 & 6 & 7 \\
\hline \multirow{2}{*}{ proton } & $\delta$ & $\delta$ & $\delta$ & $\delta$ & $\delta$ & $\delta$ & $\delta$ \\
\hline & $J(\mathrm{~Hz})$ & $J(\mathrm{~Hz})$ & $J(\mathrm{~Hz})$ & $J(\mathrm{~Hz})$ & $J(\mathrm{~Hz})$ & $J(\mathrm{~Hz})$ & $J$ in $(\mathrm{Hz})$ \\
\hline \multirow{2}{*}{3} & $3.66, \mathrm{dd}$ & $3.73, \mathrm{dd}$ & $3.66, \mathrm{dd}$ & $3.70, \mathrm{dd}$ & 3.95, br dd & $3.69, \mathrm{~d}$ & $3.94, \mathrm{dd}$ \\
\hline & $9.8,4.4$ & $4.0,1.6$ & $4.4,1.6$ & $4.3,1.7$ & $5.0,1.8$ & 3.2 & $6.7,5.1$ \\
\hline \multirow{2}{*}{6} & 4.31, br $t$ & $4.33, \mathrm{dt}$ & $4.34, \mathrm{dt}$ & $4.26, \mathrm{td}$ & 4.01, br ddd & $4.11, \mathrm{t}$ & $3.89, \mathrm{t}$ \\
\hline & 4.0 & $5.0,1.7$ & $4.9,1.4$ & $4.7,1.8$ & $10.1,3.7,1.8$ & 6.5 & 4.8 \\
\hline \multirow{2}{*}{$7 a$} & $3.27, \mathrm{dd}$ & $3.26, \mathrm{dd}$ & $3.23, \mathrm{dd}$ & $3.18, \mathrm{dd}$ & 1.92, ddd & $3.23, \mathrm{~d}$ & $2.58, \mathrm{dd}$ \\
\hline & $14.0,3.8$ & $14.0,3.8$ & $13.9,5.4$ & $14.0,4.6$ & $14.0,9.9,3.8$ & 6.5 & $13.7,4.9$ \\
\hline \multirow{2}{*}{$7 b$} & $2.95, \mathrm{dd}$ & $3.01, \mathrm{dd}$ & $3.05, \mathrm{dd}$ & $2.90, \mathrm{dd}$ & $1.62, \mathrm{ddd}$ & & $2.20, \mathrm{dd}$ \\
\hline & $13.9,4.6$ & $13.8,4.7$ & $13.8,4.7$ & $13.9,4.6$ & $14.0,10.2,4.9$ & & $13.8,6.6$ \\
\hline 8 & & & & & $1.78, \mathrm{~m}$ & & \\
\hline \multirow{2}{*}{9} & $7.20, \mathrm{~d}$ & $7.22, \mathrm{~d}$ & $7.22, d$ & $7.02, \mathrm{t}$ & $1.00, \mathrm{~d}$ & \multirow{2}{*}{$7.26, \mathrm{~m}$} & $7.04, \mathrm{~d}$ \\
\hline & 6.9 & 6.9 & 6.8 & 8.3 & 6.4 & & 7.3 \\
\hline \multirow{2}{*}{10} & $7.30, \mathrm{t}$ & $7.28, \mathrm{t}$ & $7.28, \mathrm{t}$ & $6.69, \mathrm{~d}$ & $0.96, \mathrm{~d}$ & $7.32, \mathrm{t}$ & $7.27, \mathrm{t}$ \\
\hline & 6.9 & 6.8 & 7.2 & 8.5 & 6.6 & 7.9 & 7.4 \\
\hline \multirow{2}{*}{11} & $7.26, \mathrm{t}$ & $7.25, \mathrm{t}$ & $7.23, \mathrm{t}$ & & \multirow{2}{*}{$2.12, \mathrm{~m}$} & \multirow{2}{*}{$7.26, \mathrm{~m}$} & $7.02, \mathrm{t}$ \\
\hline & 6.9 & 7.0 & 7.2 & & & & 7.3 \\
\hline $12 a$ & 0.88, ddd & \multirow{2}{*}{1.43, br m } & \multirow{2}{*}{$1.6, \mathrm{~m}$} & \multirow{2}{*}{$1.42, \mathrm{~m}$} & \multirow{2}{*}{$1.48, \mathrm{~m}$} & $3.76, \mathrm{qd}$ & $252 \mathrm{~m}$ \\
\hline & $13.8,9.4,4.4$ & & & & & $6.6,3.2$ & $2.52, \mathrm{~m}$ \\
\hline \multirow{2}{*}{$12 b$} & 0.09, ddd & & & & \multirow{2}{*}{$1.26, \mathrm{~m}$} & & $2.18, \mathrm{dd}$ \\
\hline & $13.7,9.3,4.8$ & & & & & & $13.6,6.1$ \\
\hline \multirow{2}{*}{$13 a$} & \multirow{2}{*}{1.43, br m } & \multirow{2}{*}{$0.80, \mathrm{~m}$} & $0.79, \mathrm{t}$ & \multirow{2}{*}{$0.81, \mathrm{~m}$} & $0.95, \mathrm{t}$ & $1.16, \mathrm{~d}$ & \\
\hline & & & 7.1 & & 7.5 & 6.6 & \\
\hline $13 b$ & & $0.66, \mathrm{~m}$ & & $0.66, \mathrm{~m}$ & & & \\
\hline 14 & $0.73, \mathrm{~d}$ & $0.68, \mathrm{t}$ & $0.42, \mathrm{t}$ & $0.71, \mathrm{t}$ & $1.03, \mathrm{~d}$ & & $6.84, \mathrm{~d}$ \\
\hline
\end{tabular}




\begin{tabular}{ccccccc}
\hline & 6.4 & 6.6 & 6.9 & 6.9 & 7.1 & 8.2 \\
& & & & & & $6.67, \mathrm{~d}$ \\
15 & $0.69, \mathrm{~d}$ & $0.73, \mathrm{~d}$ & & $0.76, \mathrm{~d}$ & & 8.4 \\
\hline
\end{tabular}

The ${ }^{1} \mathrm{H}$ NMR spectrum showed signals of methyl groups suggesting only aliphatic amino acids such as Leu, Ile or Val. According to the molecular formula of 5, Leu and/or Ile residues. The methyls at $\delta_{\mathrm{H}} 1.03(1 \mathrm{H}, \mathrm{d}$, $J=7.1 \mathrm{~Hz}, \mathrm{H}-14), 1.00(1 \mathrm{H}, \mathrm{d}, J=6.4 \mathrm{~Hz}, \mathrm{H}-9), 0.96(1 \mathrm{H}, \mathrm{d}, J=6.6 \mathrm{~Hz}, \mathrm{H}-10)$ and $0.95(1 \mathrm{H}, \mathrm{t}, J=7.5 \mathrm{~Hz}$, H-13) ppm together 2D NMR analysis led to a cyclo(Leu-Ile) DKP. Since there is no specific rotation described in the literature, the relative and absolute configurations will be further discussed later.

Cyclo(L-Phe-L-Thr) (6) which was isolated as a white solid showed an HRMS analysis that led to the molecular formula $\mathrm{C}_{13} \mathrm{H}_{16} \mathrm{~N}_{2} \mathrm{O}_{3}\left(m / z 271.1066\right.$ calcd for $\left.\mathrm{C}_{13} \mathrm{H}_{16} \mathrm{~N}_{2} \mathrm{O}_{3} \mathrm{Na}, 271.1059, \Delta 2.3 \mathrm{ppm}\right)$. The ${ }^{1} \mathrm{H}$ NMR signals at $\delta_{\mathrm{H}} 7.32(2 \mathrm{H}, \mathrm{t}, J=7.9 \mathrm{~Hz}, \mathrm{H}-10)$ and $7.26(3 \mathrm{H}, \mathrm{m}, \mathrm{H}-9$ and $\mathrm{H}-11)$ ppm indicated the presence of a Phe unit. The methyl at $\delta_{\mathrm{H}} 1.16(3 \mathrm{H}, \mathrm{d}, J=6.6 \mathrm{~Hz}, \mathrm{H}-13)$ ppm which correlated with the deshielded methine at $\delta_{\mathrm{H}} 3.76(1 \mathrm{H}, \mathrm{qd}, J=6.6$ and $3.2 \mathrm{~Hz}, \mathrm{H}-12) \mathrm{ppm}$ was consistent with a threonine (Thr) unit. The relative and absolute configurations cannot be discussed so far because the effect of the aromatic ring in the Thr side chain is not significant and no specific rotation data was available in the literature. Indeed, this DKP is described for the first time as a natural compound and, as far as we know, no NMR and optical data exist in the literature for this cyclic dipeptide.

Cyclo(L-Phe-L-Tyr) (7) was isolated as a white solid and the molecular formula $\mathrm{C}_{18} \mathrm{H}_{18} \mathrm{~N}_{2} \mathrm{O}_{3}$ was found by HRMS ( $m / z 333.1208$ calcd for $\mathrm{C}_{18} \mathrm{H}_{18} \mathrm{~N}_{2} \mathrm{O}_{3} \mathrm{Na}, 333.1215, \Delta-2.1 \mathrm{ppm}$ ). The ${ }^{1} \mathrm{H}$ NMR spectrum presented the characteristic signals of both Phe and Tyr units at respectively $\delta_{\mathrm{H}} 7.04(2 \mathrm{H}, \mathrm{d}, J=7.3), 7.27(2 \mathrm{H}, \mathrm{t}, J=$ 7.4) and $7.02(1 \mathrm{H}, \mathrm{t}, J=7.3) \mathrm{ppm}$ and $\delta_{\mathrm{H}} 6.84(2 \mathrm{H}, \mathrm{d}, J=8.2)$ and $6.67(2 \mathrm{H}, \mathrm{d}, J=8.4) \mathrm{ppm}$. The relative and absolute configurations were respectively determined by comparison of NMR and specific rotation data of the literature.

The study of all these DKPs raised the difficulty to gather structural and configurational data from the literature. Therefore we decided to synthesize all this DKPs in order to confirm our structure (relative and absolute configurations) and to settle the lack of stereochemical information in terms of specific rotation and/or CD. According to the DKP, the measured specific rotations of the natural compounds are not really significant because of the small amount available and the impurities corresponding to minor natural products. This fact, together with the heterogeneous values described in the literature, we so decided to use $\mathrm{CD}^{14}$ that allow use of minute quantities of the natural products obtained after repetitive HPLC purifications.

DKP optical properties. We synthesized the enantiomerically pure L-L DKPs according to the described method by M. Tullberg et al. in 2006 using microwave assisted reaction for the final cyclisation (Scheme 
1). ${ }^{9}$ The DKPs were purified by reversed phase preparative HPLC. All the natural and synthetic ${ }^{1} \mathrm{H}$ NMR spectra were superimposable and so confirmed the relative cis configurations of H-3 and H-6 for each compound.<smiles>[R]C(NC[18Cl])C(=O)O[Na]</smiles>

1. EDC, DMAP, $\mathrm{CH}_{2} \mathrm{Cl}_{2}, 1 \mathrm{~h}$

2. $\mathrm{HCl}$, dioxane, $\mathrm{MeOH}, 1 \mathrm{~h}$<smiles>[R]C(N)C(=O)NC([R])C([R])N</smiles>

$\underset{10 \min }{\mathrm{Et}_{3} \mathrm{~N}, \mathrm{H}_{2} \mathrm{O}}, \downarrow \mu \mathrm{W} 140^{\circ} \mathrm{C}$

$\begin{array}{lll} & \mathrm{R}^{1} & \mathrm{R}^{2} \\ \mathbf{1} & \text { benzyl } & i-\mathrm{Bu} \\ 2 & \text { benzyl } & \text { sec-Bu } \\ 3 & \text { benzyl } & i-\mathrm{Pr} \\ 4 & \text { sec-Bu } & 4-\mathrm{HOC}_{6} \mathrm{H}_{4} \mathrm{CH}_{2} \\ 5 & \text { sec-Bu } & i-\mathrm{Bu} \\ 6 & \text { benzyl } & \text { 1-hydroxyethyl } \\ 7 & \text { benzyl } & \text { 4- } \mathrm{HOC}_{6} \mathrm{H}_{4} \mathrm{CH}_{2}\end{array}$

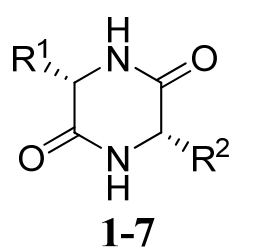

Scheme 1. Synthesis of DKP 1-7

The specific rotations of the synthetic cyclo(L-Phe-L-Leu) (1), ${ }^{15}$ cyclo(L-Phe-L-Ile) (2) ${ }^{10}$ and cyclo(L-Phe-L-Tyr) (7) ${ }^{12 b}$ measured in AcOH were similar to those described in the literature (Table 2). In the case of cyclo(L-Phe-L-Val) (3), neither the synthetic nor the natural compounds matched with the published specific rotation. Nevertheless, both synthetic and natural cyclo(L-Phe-L-Val) (3) provided the same value of -5 (c $0,3, \mathrm{AcOH})$ which we assumed to be the proper specific rotation of cyclo(L-Phe-L-Val) (3). As regard cyclo(L-Leu-L-Ile) (5), the specific rotation of the natural and the synthetic compounds are similar and confirmed the expected absolute stereochemistry.

The recorded values for the natural cyclo(L-Phe-L-Ile), cyclo(L-Tyr-L-Ile) and cyclo(L-Phe-L-Thr) (6) were not suitable to conclude. Thus, the $\mathrm{CD}$ spectra of each natural and synthetic compounds were recorded to figure out the seamless absolute configurations of each DKPs isolated from Acanthella cavernosa.

Table 3 reported the molecular CD absorptions of DKPs. The spectra of all the natural and synthetic representatives were similar and confirmed the L-L absolute stereochemistry of each DKPs isolated from Acanthella cavernosa.

Hooker et al. described DKPs CD spectra as the superimposition of one usual Cotton effect between 220 and $230 \mathrm{~nm}$ due to amide $\mathrm{n} \rightarrow \pi^{*}$ transition and a second effect due to amide $\pi \rightarrow \pi^{*}$ transitions which can be splitted (exciton effect) according to the conformation of the DKP ring. ${ }^{16}$ Indeed, a planar shape (side-chains in pseudoequatorial position) will induce a positive or negative Cotton effect whereas a flagpole-boat shape (side-chains in pseudoaxial position) will be associated with a negative or positive exciton effect because of the non parallelism of the amide $\pi \rightarrow \pi^{*}$ transition moments. 
Table 2. Specific rotations for DKPs 1-7 in $\mathrm{AcOH}$

\begin{tabular}{|c|c|c|c|}
\hline $\mathrm{DKP}$ & {$[\alpha]^{25}$ D natural } & {$[\alpha]^{25}$ D synthetic } & {$[\alpha]^{25}$ D literature } \\
\hline $\begin{array}{c}\text { Cyclo(L-Phe-L-Leu) } \\
\text { (1) }\end{array}$ & $+11(\mathrm{c} 0.46)$ & $\begin{array}{l}+12(\mathrm{c} 0.3) \\
+30(\mathrm{c} 0.3)^{a}\end{array}$ & $-8^{a, 9}$ and $+32^{, 14}$ \\
\hline $\begin{array}{c}\text { Cyclo(L-Phe-L-Ile) } \\
\text { (2) }\end{array}$ & $\begin{array}{l}\text { not pure for } \\
\qquad[\alpha]_{D}\end{array}$ & $+11(\mathrm{c} 0.3)$ & $+12^{10}$ \\
\hline $\begin{array}{c}\text { Cyclo(L-Phe-L-Val) } \\
\text { (3) }\end{array}$ & $-5(\mathrm{c} 0.47)$ & $\begin{array}{l}-5(\mathrm{c} 1.0) \text { and } \\
-11(\mathrm{c} 1.0)^{b}\end{array}$ & $-43 .^{b, 17}$ and $-64^{18}$ and $-66^{b, 19}$ \\
\hline $\begin{array}{c}\text { Cyclo(L-Tyr-L-Ile) } \\
\text { (4) }\end{array}$ & $\begin{array}{l}\text { not pure for } \\
\qquad[\alpha]_{D}\end{array}$ & $-24(\mathrm{c} 0.1)$ & - \\
\hline $\begin{array}{c}\text { Cyclo(L-Leu-L-Ile) } \\
\text { (5) }\end{array}$ & $-17(\mathrm{c} 0.47)$ & $-26(\mathrm{c} 0.5)$ & - \\
\hline $\begin{array}{c}\text { Cyclo(L-Phe-L-Thr) } \\
\text { (6) }\end{array}$ & $-12(\mathrm{c} 0.27)$ & $-42(0.4)$ & - \\
\hline $\begin{array}{c}\text { Cyclo(L-Phe-L-Tyr) } \\
\text { (7) }\end{array}$ & $-38(\mathrm{c} 0.12)$ & $\begin{array}{l}-44(\mathrm{c} 0.3) \\
-88(\mathrm{c} \quad 0.3)^{b}\end{array}$ & $-91^{b, 12 b}$ \\
\hline
\end{tabular}

${ }^{a}$ in $\mathrm{MeOH} .{ }^{b}$ in DMSO.

Table 3. Molecular CD absorptions $\left(\mathrm{cm}^{2} \cdot \mathrm{mmol}^{-1}\right)$ for DKPs 1-7

\begin{tabular}{ccc}
\hline DKP & $\Delta \varepsilon_{\text {natural }}\left(\lambda_{\text {max }}\right)^{\mathrm{a}}$ & $\Delta \varepsilon_{\text {synthetic }}\left(\lambda_{\max }\right)^{\mathrm{a}}$ \\
\hline $\mathbf{1}$ & $-3.6(224) ;-3.5(216)$ & $-7.5(224) ;-7.2(216)$ \\
$\mathbf{2}$ & $+0.8(223) ;-2.5(206)$ & $+2.3(223) ;-3.2(209)$ \\
$\mathbf{3}$ & $+1.1(225) ;-6.3(204)$ & $+3.4(225) ;-15.8(205)$ \\
$\mathbf{4}$ & $+0.4(277) ;+0.6(224) ;-1.0(209)$ & $+0.6(277) ;+1.8(223) ;-1.0(209)$ \\
$\mathbf{5}$ & $-6.7(205)$ & $-10.3(205)$ \\
$\mathbf{6}$ & $-14.0(212)$ & $-16.3(213)$ \\
$\mathbf{7}$ & $+0.1(277) ;-3.1(203)$ & $+0.2(277) ;-3.7(203)$ \\
\hline
\end{tabular}

${ }^{\mathrm{a}}$ recorded in $\mathrm{MeOH}$ conc. $10^{-5} \mathrm{M}$

As reported in Figure 2, cyclo(L-Phe-L-Ile) (2), cyclo(L-Tyr-L-Ile) (4) and cyclo(L-Phe-L-Val) (3) spectra showed the beginning of a positive-negative-positive pattern (positive $n \rightarrow \pi^{*}$ transition and $\pi \rightarrow \pi^{*}$ exciton 
effect) which were in accordance with a flagpole-boat shape previously proposed in ${ }^{1} \mathrm{H}$ NMR by the shielding effects of the aromatic rings on the aliphatic side-chains. ${ }^{20}$

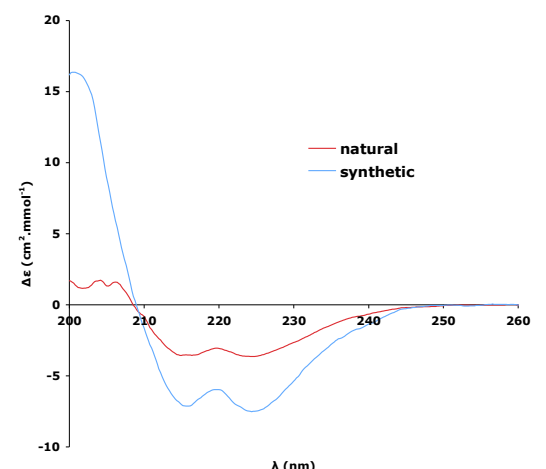

cyclo(L-Phe-L-Leu) (1)

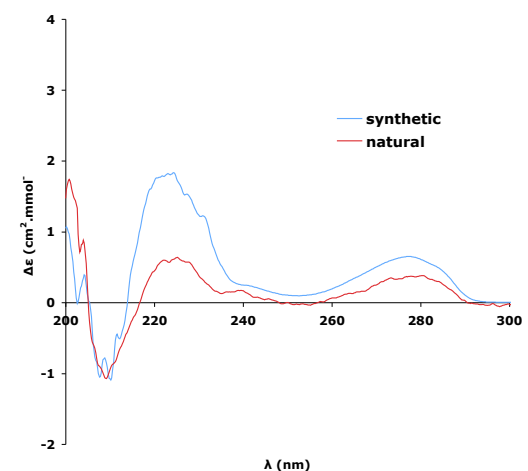

cyclo(L-Tyr-L-Ile) (4)

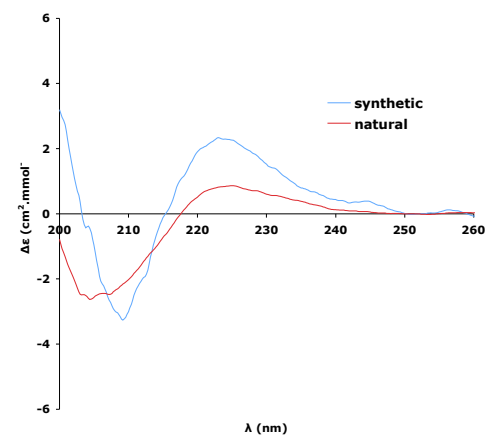

cyclo(L-Phe-L-Ile) (2)

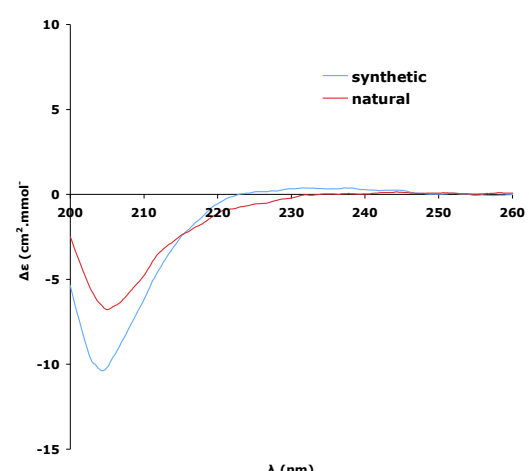

cyclo(L-Leu-L-Ile) (5)

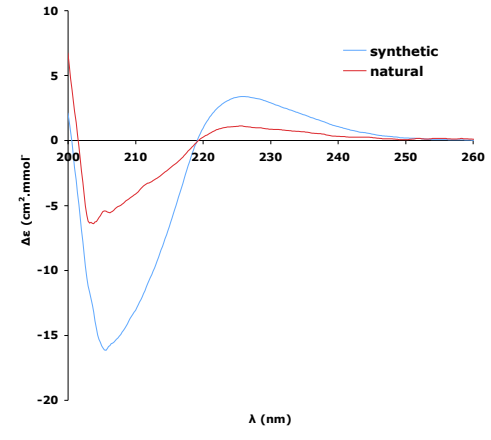

cyclo(L-Phe-L-Val) (3)

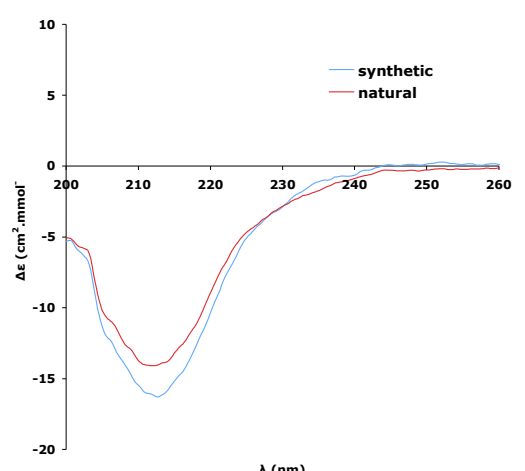

cyclo(L-Phe-L-Thr) (6)

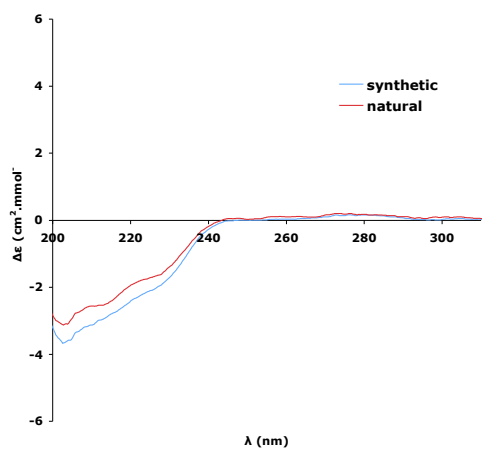

cyclo(L-Phe-L-Tyr) (7)

Figure 2. Comparison of CD spectra of natural (red) and synthetic (blue) DKPs 1-7 in $\mathrm{MeOH}\left(10^{-5} \mathrm{M}\right)$

Cyclo(L-Leu-L-Ile) (5) presented the beginning of a single exciton effect and a small $\mathrm{n} \rightarrow \pi^{*}$ positive effect at $240 \mathrm{~nm}$ previously noticed by Hooker for the cyclo(L-Val $)_{2}$ but not by Tanihara for the cyclo(L-Leu $)_{2}{ }^{21,22}$ The presence of this small effect was not discussed but both concluded with a flagpole-boat conformation, which could be explained by the lipophilic interaction between the aliphatic 
side-chains. Cyclo(L-Leu-L-Ile) (5) has been described for the first time as the L-L enantiomer because, in both cited publications, the ${ }^{1} \mathrm{H}$ and ${ }^{13} \mathrm{C}$ NMR did not match perfectly our results.

Cyclo(L-Phe-L-Thr) (6) showed a simple negative effect which certainly due to a amide $\pi \rightarrow \pi^{*}$ transition because of the short wavelength value. Thus, this DKP ring conformation was planar. This conformation could be explained by a repulsive interaction between the aromatic ring and the hydroxyl of the Thr side-chain.

Cyclo(L-Phe-L-Leu) (1) spectra showed the beginning of an exciton effect with two negative extremes at 216 and $224 \mathrm{~nm}$. Hooker model led us to explain this phenomenon by the usual $\pi \rightarrow \pi^{*}$ exciton effect for the extremes at 216 (negative) and 200 (positive) nm superimposed to an unusual negative $n \rightarrow \pi^{*}$ Cotton effect. So far, this interpretation could confirm the flagpole-boat shape of the DKP ring previously observed in ${ }^{1} \mathrm{H}$ NMR but its rather difficult to give any significance to the observed negative Cotton effect.

Cyclo(L-Phe-L-Tyr) (7) spectra consisted in a broad negative signal between 200 and $240 \mathrm{~nm}$. This "wave-shaped" signal could be the superimposition of several different Cotton and exciton effects. Indeed, in diaryl-substituted DKPs cases, the analysis of the CD spectra is difficult because each aromatic chromophores had four electronic transitions (two $\mathrm{B}$ transitions, ${ }^{1} \mathrm{~L}_{\mathrm{a}}$ and ${ }^{1} \mathrm{~L}_{\mathrm{b}}$ transitions) which could interact between each other to afford complex Cotton effects. ${ }^{20,23}$

In conclusion, the study of the marine sponge Acanthella cavernosa led to the isolation 7 DKPs including the rare cyclo(L-Phe-L-Thr) and cyclo(L-Tyr-L-Ile) along with various secondary metabolites of the deoxyribonucleotide and decarboxylated amino acids familie. The analysis of their optical properties was achieved to clarify the literature ambiguity regarding natural and synthetic DKPs.

\section{EXPERIMENTAL}

\section{General Experimental Procedures}

Optical rotations were measured in acetic acid, methanol or DMSO (see Table 2) on a Jasco P1010 polarimeter. The CD spectra were obtained via a Jasco Spectropolarimeter J-810. The IR spectra were measured (neat) on a Perkin Elmer BX-FT-IR spectrometer. The UV spectrum was recorded on a waters 996 Photodiode Array detector in the HPLC solvent. NMR experiments were recorded on a Bruker Avance $600 \mathrm{MHz}$ and DRX 500 and $300 \mathrm{MHz}$ spectrometers. The chemical shifts were referenced to the residual solvent signal $\left(\mathrm{MeOD} \delta_{\mathrm{H}}=3.31\right.$ and $\delta_{\mathrm{C}}=49.0 ; \mathrm{CDCl}_{3} \delta_{\mathrm{H}}=7.26$ and $\delta_{\mathrm{C}}=77.2 ;$ DMSO $-d_{6} \delta_{\mathrm{H}}=2.50$ and $\delta_{\mathrm{C}}$ = 39.5). HRMS data were obtained with a hybrid linear trap/orbitrap mass spectrometer (LTQ-orbitrap, Thermofisher) in electrospray ionization mode by direct infusion of the purified compounds. Preparative HPLC was performed on an autoprep system (Waters 600 controller and Waters 600 pump with a waters 966 PhotoDiode Array Detector).

\section{Collection and identification of the sponge}


The sponge was collected by hand using SCUBA off the coast of Vanua Levu (Fiji island) at a depth of $23 \mathrm{~m}$ on the 10/05/2007. It was identified by Dr John N. A. Hooper (Queensland Museum, Brisbane, Australia) as Acanthella cavernosa Dendy, 1921. A voucher sample is kept there under the accessing number G324594.

\section{Extraction and isolation}

The lyophilised powder of sponge powder $(180 \mathrm{~g})$ was consecutively extracted with $\mathrm{CH}_{2} \mathrm{Cl}_{2}(2 \times 2 \mathrm{~L})$ and $\mathrm{MeOH}(2 \times 2 \mathrm{~L})$. The $\mathrm{MeOH}$ extract $(50 \mathrm{~g})$ was desalted by a $n-\mathrm{BuOH}-\mathrm{H}_{2} \mathrm{O}$ liquid-liquid extraction to afford $6.2 \mathrm{~g}$ of the $n$-BuOH extract. This extract was subjected to a RP-18 silica gel flash chromatography eluted with a decreasing polarity gradient of $\mathrm{H}_{2} \mathrm{O} / \mathrm{MeOH}, 1: 0$ to $0: 1$, then $\mathrm{MeOH} / \mathrm{CH}_{2} \mathrm{Cl}_{2}, 1: 0$ to $0: 1$. The $\mathrm{H}_{2} \mathrm{O} / \mathrm{MeOH}$ 3:1 fraction was purified by reverse phase preparative HPLC (column Waters Sunfire $19 \times 150$ mm, $5 \mu \mathrm{m}$; gradient: $\mathrm{H}_{2} \mathrm{O} / \mathrm{MeCN} /$ formic acid from 90:10:0.1 to 60:40:0.1 in $30 \mathrm{~min}$ ) to afford pure cyclo(L-Tyr-L-Ile) (1.5 mg), cyclo(L-Phe-L-Val) (1.9 mg), cyclo(L-Leu-L-Ile) (1.9 mg), cyclo(L-Phe-L-Leu) $\left(3.7 \mathrm{mg}\right.$ ) and cyclo(L-Phe-L-Ile) $(\mathbf{1}, 1.9 \mathrm{mg})$. The $\mathrm{H}_{2} \mathrm{O}$ fraction was purified by normal phase preparative HPLC (column Waters Hilic $19 \times 150 \mathrm{~mm}, 5 \mu \mathrm{m}$; gradient from $\mathrm{MeCN} / \mathrm{H}_{2} \mathrm{O} /$ ammonium formate: 95/0/5 to $65 / 35 / 5$ in $30 \mathrm{~min})$ to obtain pure deoxycytidin $(10 \mathrm{mg})$, cytosine $(1 \mathrm{mg})$, deoxynebularine $(3 \mathrm{mg})$, deoxyinosine (4 mg), tryptamine (7 mg), phenylethylamine (1 mg), 2-(4-hydroxyphenyl)ethylamine (1 mg), cyclo(L-Phe-L-Thr) (1.1 mg) and cyclo(L-Phe-L-Tyr) (0.6 mg).

Finally, kaihinol Y (10.3 mg) were isolated by a reverse phase preparative HPLC (column X-Bridge $19 \times$ $150 \mathrm{~mm}, 5 \mu \mathrm{m}$; gradient from $\mathrm{H}_{2} \mathrm{O} / \mathrm{MeOH} /$ formic acid to $30 / 70 / 0.1$ to $0 / 100 / 0.1$ in $30 \mathrm{~min}$ ) of the $\mathrm{H}_{2} \mathrm{O}: \mathrm{MeOH}$ 1:5 fraction.

General procedure for coupling reaction: the methyl ester of the $\mathrm{C}$-terminal amino acid ( 1 eq) and the Boc-protected N-terminal amino acid (1.1 eq) were dissolved in dry solvent $\mathrm{CH}_{2} \mathrm{Cl}_{2}(15 \mathrm{~mL})$, followed by addition of DMAP (1 eq). The reaction mixture was stirred for $5 \mathrm{~min}$ at $\mathrm{rt}$ whereupon EDC (1.3 eq) was added. The reaction was thereafter stirred for $1 \mathrm{~h}$ at $\mathrm{rt}$. The reaction mixture was then washed with $\mathrm{H}_{2} \mathrm{O}$. The aqueous layer was extracted with AcOEt. The organic layer was dried on $\mathrm{MgSO}_{4}$, concentrated in vacuo and the crude product was purified by flash chromatography.

General procedure for deprotection: the pure compound from the coupling reaction was dissolved in $\mathrm{MeOH}$ ( $7 \mathrm{~mL}$ ), and $\mathrm{HCl}$ (4M in dioxane) (20 eq.) was added. The reaction mixture was stirred at $\mathrm{rt}$ for $1 \mathrm{~h}$ and then concentrated in vacuo, to give pure deprotected compound with a quantitative yield.

General procedure for dipeptide cyclisation: the hydrochloride salt of the deprotected dipeptide ( 1 eq) was dissolved in $\mathrm{H}_{2} \mathrm{O}(3 \mathrm{~mL})$ and 2.5 equivalents of triethylamine was added. The microwave assisted heated reactions were run for $10 \mathrm{~min}$ at $140{ }^{\circ} \mathrm{C}$. The crude product precipitated spontaneously and the reaction mixture was filtered. The crude product was purified by $\mathrm{C} 18$ reversed phase preparative HPLC 
$\left(\mathrm{H}_{2} \mathrm{O}+0.1 \%\right.$ formic acid/MeOH $+0.1 \%$ formic acid $)$ to give the pure DKPs.

\section{Cyclo(L-Phe-L-Leu) (1):}

Coupling: L-Leu-OMe (500 mg; $2.7 \mathrm{mmol})$, Boc-L-phenylalanine (800 mg; $3.0 \mathrm{mmol})$, DMAP (340 mg; $2.7 \mathrm{mmol})$ and $\mathrm{EDC}(680 \mathrm{mg} ; 3.6 \mathrm{mmol})$ in $\mathrm{CH}_{2} \mathrm{Cl}_{2}$ as described in the general procedure. Flash chromatography, Heptane:AcOEt as eluent. Pure compound was isolated as a white powder (920 mg; 85\%). Deprotection: the $N$-Boc-L-Phe-L-Leu-OMe (200 mg; $0.51 \mathrm{mmol})$ was dissolved in $\mathrm{MeOH}$ and $\mathrm{HCl} 4 \mathrm{M}$ in dioxane $(2.5 \mathrm{~mL} ; 10.2 \mathrm{mmol})$ as described in the general procedure. The mixture was concentrated in vacuo to give pure deprotected compound (190 mg; quant.).

Cyclisation: The deprotected compound L-Phe-L-Leu-OMe (140 mg; $0.42 \mathrm{mmol})$ and triethylamine (148 $\mu \mathrm{L} ; 1.02 \mathrm{mmol}$ ) were reacted as described in the general procedure. Pure $\mathbf{1}$ was isolated as white powder (52 mg; 48\%). White solid. $[\alpha]^{25}{ }_{\mathrm{D}}+12.5$ (c 0.3, AcOH); ${ }^{1} \mathrm{H}$ NMR (500 MHz, MeOD) $\delta 7.30(2 \mathrm{H}, \mathrm{t}, J=6.9$ Hz, H-10), 7.26 (1H, t, $J=6.9$ Hz, H-11), 7.20 (2H, d, $J=6.9$ Hz, H-9), 4.31 (1H, br t, $J=4.0 \mathrm{~Hz}, \mathrm{H}-6), 3.66$ $(1 \mathrm{H}, \mathrm{dd}, J=9.8$ and $4.4 \mathrm{~Hz}, \mathrm{H}-3), 3.27(1 \mathrm{H}, \mathrm{dd}, J=14.0$ and $3.8 \mathrm{~Hz}, \mathrm{H}-7 \mathrm{a}), 2.95(1 \mathrm{H}, \mathrm{dd}, J=13.9$ and 4.6 Hz, H-7b), 1.43 (1H, br m, H-13), 0.88 (1H, ddd, $J=13.8,9.4$ and $4.4 \mathrm{~Hz}, \mathrm{H}-12 \mathrm{a}), 0.73$ (3H, d, $J=6.4 \mathrm{~Hz}$, $\mathrm{H}-14), 0.69(3 \mathrm{H}, \mathrm{d}, J=6.4 \mathrm{~Hz}, \mathrm{H}-15), 0.09(1 \mathrm{H}, \mathrm{ddd}, J=13.7,9.3$ and $4.8 \mathrm{~Hz}, \mathrm{H}-12 \mathrm{~b}) ;{ }^{13} \mathrm{C} \mathrm{NMR}(75 \mathrm{MHz}$, $\left.\mathrm{CDCl}_{3}\right) \delta 167.8$ and $167.6(\mathrm{C}, \mathrm{C} 2$ and C5), 135.1 (C, C-8), $130.2(\mathrm{CH}, \mathrm{C}-9), 129.2(\mathrm{CH}, \mathrm{C}-10), 127.8(\mathrm{CH}$, C-11), 56.4 (CH, C-6), $53.4(\mathrm{CH}, \mathrm{C}-3), 43.1\left(\mathrm{CH}_{2}, \mathrm{C}-12\right), 40.2\left(\mathrm{CH}_{2}, \mathrm{C}-7\right), 23.2(\mathrm{CH}, \mathrm{C}-13), 22.8$ and 20.9 $\left(\mathrm{CH}_{3}, \mathrm{C}-14\right.$ and C-15); HRMS-ESI ${ }^{+} m / z 283.1412$ (calcd for $\mathrm{C}_{15} \mathrm{H}_{20} \mathrm{~N}_{2} \mathrm{O}_{2} \mathrm{Na}, 283.1422, \Delta$ - 3.7 ppm.

\section{Cyclo(L-Phe-L-Ile) (2):}

Coupling: L-Ile-OMe (500 mg; $2.7 \mathrm{mmol}$ ), Boc-L-phenylalanine (800 mg; 3.0 mmol), DMAP (340 mg; 2.7 $\mathrm{mmol}$ ) and EDC (680 mg; $3.6 \mathrm{mmol})$ were reacted in $\mathrm{CH}_{2} \mathrm{Cl}_{2}$. Flash chromatography heptane:AcOEt as eluent. Pure compound was isolated as a white powder (910 mg; 84\%).

Deprotection: the N-Boc-L-Phe-L-Leu-OMe (200 mg; $0.51 \mathrm{mmol})$ was dissolved in $\mathrm{MeOH}$ and $\mathrm{HCl} 4 \mathrm{M}$ in dioxane $(2.5 \mathrm{~mL} ; 10.2 \mathrm{mmol})$ as described in the general procedure. The mixture was concentrated in vacuo to give pure deprotected compound (160 g; quant.).

Cyclisation: the deprotected compound L-Phe-L-Ile-OMe (100 mg; $0.31 \mathrm{mmol})$ and triethylamine $(109 \mu \mathrm{L}$; $0.75 \mathrm{mmol}$ ) were reacted as described in the general procedure. The reaction was not complete, but enough material was isolated by HPLC for CD analysis. Pure 2 was isolated as white powder (7 mg; 8\%). White solid. $[\alpha]^{25}+11(\mathrm{c} 0.3, \mathrm{AcOH}) ;{ }^{1} \mathrm{H}$ NMR $(500 \mathrm{MHz}, \mathrm{MeOD}) \delta 7.28(2 \mathrm{H}, \mathrm{t}, J=6.8 \mathrm{~Hz}, \mathrm{H}-10), 7.25(1 \mathrm{H}, \mathrm{t}$, $J=7.0 \mathrm{~Hz}, \mathrm{H}-11), 7.22(2 \mathrm{H}, \mathrm{d}, J=6.9 \mathrm{~Hz}, \mathrm{H}-9), 4.33(1 \mathrm{H}, \mathrm{dt}, J=5.0$ and $1.7 \mathrm{~Hz}, \mathrm{H}-6), 3.73(1 \mathrm{H}, \mathrm{dd}, J=4.0$ and $1.6 \mathrm{~Hz}, \mathrm{H}-3), 3.26(1 \mathrm{H}, \mathrm{dd}, J=14.0$ and $4.8 \mathrm{~Hz}, \mathrm{H}-7 \mathrm{a}), 3.01(1 \mathrm{H}, \mathrm{dd}, J=13.8$ and $4.7 \mathrm{~Hz}, \mathrm{H}-7 \mathrm{~b}), 1.43$ (1H, br m, H-12), 0.80 (1H, m, H-13a), 0.73 (3H, d, $J=7.0 \mathrm{~Hz}, \mathrm{H}-15), 0.68$ (3H, t, $J=6.6 \mathrm{~Hz}, \mathrm{H}-14), 0.66$ $(1 \mathrm{H}, \mathrm{m}, \mathrm{H}-13 \mathrm{~b}) ;{ }^{13} \mathrm{C}$ NMR (75 MHz, DMSO-d 6 ) $\delta 167.3$ and 167.2 (C, C-2 and C-5), 137.2 (C, C-8), 131.3 (CH, C-9), 128.8 (CH, C-10), 127.4 (CH, C-11), 59.6 (CH, C-3), 55.9 (CH, C-6), 38.7 (CH, C-12), 38.5 
$\left(\mathrm{CH}_{2}, \mathrm{C}-7\right), 24.1\left(\mathrm{CH}_{2}, \mathrm{C}-13\right), 15.3$ and $12.7\left(\mathrm{CH}_{3}, \mathrm{C}-14\right.$ and C-15). HRMS-ESI ${ }^{+} \mathrm{m} / z$ 283.1418 (calcd for $\left.\mathrm{C}_{15} \mathrm{H}_{20} \mathrm{~N}_{2} \mathrm{O}_{2} \mathrm{Na}, 283.1422, \Delta-1.4 \mathrm{ppm}\right)$.

\section{Cyclo(L-Phe-L-Val) (3):}

Coupling: L-Val-OMe (500 mg; 3.0 mmol), Boc-L-phenylalanine (870 g; 3.3 mmol), DMAP (360 g; 3.0 $\mathrm{mmol})$ and $\mathrm{EDC}(740 \mathrm{mg} ; 3.9 \mathrm{mmol})$ were reacted in $\mathrm{CH}_{2} \mathrm{Cl}_{2}$ as described in the general procedure. The crude product was purified using heptane:AcOEt as eluent. Pure compound was isolated as a white powder $(1.0 \mathrm{~g} ; 88 \%)$.

Deprotection: $N$-Boc-L-Phe-L-Val-OMe $(200 \mathrm{~g}$; $0.53 \mathrm{mmol})$ was dissolved in $\mathrm{MeOH}$ and $\mathrm{HCl} 4 \mathrm{M}$ in dioxane $(2.7 \mathrm{~mL} ; 10.6 \mathrm{mmol})$ as described in the general procedure. The mixture was concentrated in vacuo to give pure deprotected compound ( $0.140 \mathrm{~g}$; quant.).

Cyclisation: the deprotected compound L-Phe-L-Val-OMe $(20 \mathrm{mg} ; 0.07 \mathrm{mmol})$ and triethylamine $(26 \mu \mathrm{L}$; $0.18 \mathrm{mmol})$ were reacted as described in the general procedure. Pure 3 was isolated as white powder $(9 \mathrm{mg}$; 47\%). White solid. $[\alpha]_{\mathrm{D}}^{25}-5$ (c 1.0, AcOH); $[\alpha]_{\mathrm{D}}^{25}-11.4$ (c 1.0, DMSO- $\left.d_{6}\right) ; 1 \mathrm{H} \mathrm{NMR}$ (500 MHz, DMSO) $\delta$ $7.28(2 \mathrm{H}, \mathrm{t}, J=7.2 \mathrm{~Hz}, \mathrm{H}-10), 7.23(1 \mathrm{H}, \mathrm{t}, J=7.2 \mathrm{~Hz}, \mathrm{H}-11), 7.22(2 \mathrm{H}, \mathrm{d}, J=6.8 \mathrm{~Hz}, \mathrm{H}-9), 4.34$ (td, $J=4.88$ and $1.4 \mathrm{~Hz}, \mathrm{H}-6), 3.66(1 \mathrm{H}, \mathrm{dd}, J=4.4$ and $1.6 \mathrm{~Hz}, \mathrm{H}-3), 3.23(\mathrm{dd}, J=13.9$ and $5.4 \mathrm{~Hz}, \mathrm{H}-7 \mathrm{a}), 3.05(\mathrm{dd}, J=$ 13.8 and $4.7 \mathrm{~Hz}, \mathrm{H}-7 \mathrm{~b}), 1.6(1 \mathrm{H}, \mathrm{m}, \mathrm{H}-12), 0.79$ (3H, d, $J=7.1 \mathrm{~Hz}, \mathrm{H}-13), 0.42$ (3H, d, $J=6.9 \mathrm{~Hz}, \mathrm{H}-14)$;

${ }^{13} \mathrm{C}$ NMR (75 MHz, MeOD) $\delta 167.6$ and 166.5 (C, C-2 and C-5), 136.3 (C, C-8), 130.3 (CH, C-9), 127.9 (CH, C-10), 126.4 (CH, C-11), $59.2(\mathrm{CH}, \mathrm{C}-3), 55.0(\mathrm{CH}, \mathrm{C}-6), 37.8\left(\mathrm{CH}_{2}, \mathrm{C}-7\right), 31.0(\mathrm{CH}, \mathrm{C}-12), 18.2$ and $16.2\left(\mathrm{CH}_{3}, \mathrm{C}-13\right.$ and C-14); HRMS-ESI ${ }^{+} \mathrm{m} / z 269.1257$ (calcd for $\mathrm{C}_{14} \mathrm{H}_{18} \mathrm{~N}_{2} \mathrm{O}_{2} \mathrm{Na}, 269.1266, \Delta-3.3 \mathrm{ppm}$ ).

\section{Cyclo(L-Tyr-L-Ile) (4):}

Coupling: L-Tyr-OMe (55O mg; 2.4 mmol), Boc-L-isoleucine (500 mg; 2.16 mmol), DMAP (260 mg; 2.2 mmol) and EDC (540 mg; $2.8 \mathrm{mmol}$ ) were reacted in $\mathrm{CH}_{2} \mathrm{Cl}_{2}$ as described in the general procedure. The crude product was purified using heptane:AcOEt as eluent : white powder (510 mg; 58\%).

Deprotection: The $N$-Boc-L-Tyr-L-Ile-OMe (260 mg; $0.63 \mathrm{mmol})$ was dissolved in $\mathrm{MeOH}$ and $\mathrm{HCl} 4 \mathrm{M}$ in dioxane $(3.0 \mathrm{~mL} ; 12.5 \mathrm{mmol})$ as described in the general procedure. The mixture was concentrated in vacuo to give pure deprotected compound (0.215 g; quant.).

Cyclisation: L-Tyr-L-Ile-OMe (115 mg; $0.33 \mathrm{mmol})$ and triethylamine $(116 \mu \mathrm{L} ; 1.02 \mathrm{mmol})$ were reacted as described in the general procedure. Pure 4 was isolated as white powder (23 mg; 25\%). White solid. $[\alpha]^{25}{ }_{\mathrm{D}}-24(\mathrm{c} 0.1, \mathrm{MeOH}) ;{ }^{1} \mathrm{H}$ NMR $(500 \mathrm{MHz}, \mathrm{MeOD}) \delta 7.02(2 \mathrm{H}, \mathrm{t}, J=8.3 \mathrm{~Hz}, \mathrm{H}-9), 6.69(2 \mathrm{H}, \mathrm{d}, J=8.5$ Hz, H-10), 4.26 (td, $J=4.74$ and $1.76 \mathrm{~Hz}, \mathrm{H}-6), 3.7$ (dd, $J=4.27$ and $1.74 \mathrm{~Hz}, \mathrm{H}-3), 3.18$ (dd, $J=14.01$ and $4.59 \mathrm{~Hz}, \mathrm{H}-7 \mathrm{a}), 2.9$ (dd, $J=13.98$ and $4.64 \mathrm{~Hz}, \mathrm{H}-7 \mathrm{~b}), 1.42$ (1H, m, H-12), 0.81 (1H, m, H-13a), 0.76 (3H, $\mathrm{d}, J=7.0 \mathrm{~Hz}, \mathrm{H}-15), 0.71(3 \mathrm{H}, \mathrm{t}, J=6.9 \mathrm{~Hz}, \mathrm{H}-14), 0.66(1 \mathrm{H}, \mathrm{m}, \mathrm{H}-13 \mathrm{~b}) ;{ }^{13} \mathrm{C} \mathrm{NMR}(75 \mathrm{MHz}, \mathrm{MeOD}) \delta$ 168.8 and 167.3 (C, C2 and C5), 132.6 (CH, C-9), 116.3 (CH, C-10), 60.9 (CH, C-3), 57.4 (CH, C-6), 39.8 
$\left(\mathrm{CH}_{2}, \mathrm{C}-7\right), 38.9(\mathrm{CH}, \mathrm{C}-12), 24.7\left(\mathrm{CH}_{2}, \mathrm{C}-13\right), 15.4$ and $11.9\left(\mathrm{CH}_{3}, \mathrm{C}-13\right.$ and C-14); HRMS-ESI ${ }^{+} \mathrm{m} / z$ 299.1362 (calcd for $\mathrm{C}_{15} \mathrm{H}_{20} \mathrm{~N}_{2} \mathrm{O}_{3} \mathrm{Na}, 299.1372, \Delta-3.2 \mathrm{ppm}$ ).

\section{Cyclo(L-Leu-L-Ile) (5):}

Coupling: L-Leu-OMe (500 mg; 2.7 mmol), Boc-L-isoleucine (700 mg; 3.0 mmol), DMAP (0.34 g; 2.7 mmol) and $\mathrm{EDC}(0.68 \mathrm{~g} ; 3.6 \mathrm{mmol})$ were reacted in $\mathrm{CH}_{2} \mathrm{Cl}_{2}$ as described in the general procedure. The crude product was purified using heptane:AcOEt as eluent. Pure compound was isolated as a white powder (750 mg; 76\%).

Deprotection: $N$-Boc-L-Ile-L-Leu-OMe (200 mg; $0.56 \mathrm{mmol}$ ) was dissolved in $\mathrm{MeOH}$ and $\mathrm{HCl} 4 \mathrm{M}$ in dioxane $(2.8 \mathrm{~mL} ; 11.2 \mathrm{mmol})$ as described in the general procedure. The mixture was concentrated in vacuo to give pure deprotected compound (0.160 g; quant.).

Cyclisation: The deprotected compound L-Ile-L-Leu-OMe (112 mg; $0.38 \mathrm{mmol})$ and triethylamine (133 $\mu \mathrm{L} ; 0.92 \mathrm{mmol}$ ) were reacted as described in the general procedure. Pure 5 was isolated as white powder (48 mg; 55\%). White solid. $[\alpha]^{25}{ }_{\mathrm{D}}-26$ (c 0.5, AcOH); ${ }^{1} \mathrm{H}$ NMR (500 MHz, $\left.\mathrm{CDCl}_{3}\right) \delta 5.94(1 \mathrm{H}, \mathrm{s}, \mathrm{NH}), 5.79$ $(1 \mathrm{H}, \mathrm{s}, \mathrm{NH}), 4.01(1 \mathrm{H}, \mathrm{br} \mathrm{ddd}, J=10.1,3.7$ and $1.8 \mathrm{~Hz}, \mathrm{H}-6), 3.95$ (1H, br dd, $J=5.0$ and 1.8 Hz, H-3), 2.12 (1H, m, H-11), 1.92 (1H, ddd, $J=14.0,9.9$ and $3.8 \mathrm{~Hz}, \mathrm{H}-7 \mathrm{a}), 1.78$ (1H, m, H-8), 1.62 (ddd, $J=14.0,10.2$ and $4.9 \mathrm{~Hz}, \mathrm{H}-7 \mathrm{~b}), 1.48(1 \mathrm{H}, \mathrm{m}, \mathrm{H}-12 \mathrm{a}), 1.26(1 \mathrm{H}, \mathrm{m}, \mathrm{H}-12 \mathrm{~b}), 1.03(1 \mathrm{H}, \mathrm{d}, J=7.1 \mathrm{~Hz}, \mathrm{H}-14), 1.00(1 \mathrm{H}, \mathrm{d}$, $J=6.4 \mathrm{~Hz}, \mathrm{H}-9), 0.96(1 \mathrm{H}, \mathrm{d}, J=6.6 \mathrm{~Hz}, \mathrm{H}-10), 0.95(1 \mathrm{H}, \mathrm{t}, J=7.5 \mathrm{~Hz}, \mathrm{H}-13) ;{ }^{13} \mathrm{C} \mathrm{NMR}\left(75 \mathrm{MHz}, \mathrm{CDCl}_{3}\right)$ $\delta 168.8$ (C, C-2), 167.3 (C, C-5), 60.1 (CH, C-6), 53.2 (CH, C-3), $43.6\left(\mathrm{CH}_{2}, \mathrm{C}-7\right), 38.3$ (CH, C-11), 24.4 $\left(\mathrm{CH}_{2}, \mathrm{C}-12\right), 24.1$ (CH, C-8), $23.5\left(\mathrm{CH}_{3}, \mathrm{C}-9\right), 21.2\left(\mathrm{CH}_{3}, \mathrm{C}-10\right), 15.4\left(\mathrm{CH}_{3}, \mathrm{C}-14\right), 11.9\left(\mathrm{CH}_{3}, \mathrm{C}-15\right)$. HRMS-ESI $^{+} m / z 263.1728$ (calcd for $\mathrm{C}_{13} \mathrm{H}_{24} \mathrm{~N}_{2} \mathrm{O}_{2} \mathrm{Na}, 263.1735, \Delta-2.6 \mathrm{ppm}$.

\section{Cyclo(L-Phe-L-Thr) (6):}

Coupling: L-Thr-OMe (500 mg; 2.9 mmol), Boc-L-phenylalanine (860 mg; 3.2 mmol), DMAP (360 mg; $2.9 \mathrm{mmol})$ and $\mathrm{EDC}(730 \mathrm{mg} ; 3.8 \mathrm{mmol})$ were reacted in $\mathrm{CH}_{2} \mathrm{Cl}_{2}$ as described in the general procedure. The crude product was purified using heptane:AcOEt as eluent. Pure compound was isolated as a white powder (800 mg; 72\%).

Deprotection: $N$-Boc-L-Phe-L-Thr-OMe $(0.200 \mathrm{mg}$; $0.53 \mathrm{mmol})$ was dissolved in $\mathrm{MeOH}$ and $\mathrm{HCl} 4 \mathrm{M}$ in dioxane $(2.7 \mathrm{~mL} ; 10.5 \mathrm{mmol})$ as described in the general procedure. The mixture was concentrated in vacuo to give pure deprotected compound (150 mg; quant.).

Cyclisation: deprotected compound L-Phe-L-Thr-OMe $(57 \mathrm{mg} ; 0.18 \mathrm{mmol})$ and triethylamine $(64 \mu \mathrm{L} ; 0.45$ mmol) were reacted as described in the general procedure. The reaction was not complete. The reaction mixture was extracted with AcOEt. The organic layer was dried on $\mathrm{MgSO}_{4}$, concentrated in vacuo, (11 mg crude extract) and then purified by reversed phase HPLC. Pure 6 was isolated as a white powder (5 mg; 11\%). White solid. $[\alpha]^{25}-42^{\circ}$ (c 0.4, AcOH); ${ }^{1} \mathrm{H}$ NMR (500 MHz, MeOD) $\delta 7.32(2 \mathrm{H}, \mathrm{t}, J=7.9 \mathrm{~Hz}, \mathrm{H}-10)$, 
$7.26(3 \mathrm{H}, \mathrm{m}, \mathrm{H}-9$ and $\mathrm{H}-11), 4.11(1 \mathrm{H}, \mathrm{t}, J=6.5 \mathrm{~Hz}, \mathrm{H}-6), 3.76(1 \mathrm{H}, \mathrm{qd}, J=6.6$ and $3.2 \mathrm{~Hz}, \mathrm{H}-12), 3.69(1 \mathrm{H}$, $\mathrm{d}, J=3.2 \mathrm{~Hz}, \mathrm{H}-3), 3.23(2 \mathrm{H}, \mathrm{d}, J=6.5 \mathrm{~Hz}, \mathrm{H}-7), 1.16(3 \mathrm{H}, \mathrm{d}, J=6.6 \mathrm{~Hz}, \mathrm{H}-13) ;{ }^{13} \mathrm{C} \mathrm{NMR}(75 \mathrm{MHz}$, MeOD) $\delta 170.4$ and 169.2 (C, C-2 and C-5), 138.0 (C, C-8), $131.0(\mathrm{CH}, \mathrm{C}-9), 129.7$ (CH, C-10), $128.0(\mathrm{CH}$, C-11), 69.3 (CH, C-12), 62.2 (CH, C-3), 58.0 (CH, H-6), $42.4\left(\mathrm{CH}_{2}, \mathrm{C}-7\right), 20.0\left(\mathrm{CH}_{3}, \mathrm{C}-13\right)$; HRMS-ESI ${ }^{+}$ $m / z 271.1066$ (calcd for $\mathrm{C}_{13} \mathrm{H}_{16} \mathrm{~N}_{2} \mathrm{O}_{3} \mathrm{Na}, 271.1059, \Delta 2.3 \mathrm{ppm}$ ).

Cyclo(L-Phe-L-Tyr) (7) ${ }^{12}$ :

Coupling: L-Tyr-OMe (500 mg; $1.88 \mathrm{mmol})$, Boc-L-phenylalanine (480 mg; $2.1 \mathrm{mmol})$, DMAP (230 g; $1.88 \mathrm{mmol}$ ) and $\operatorname{EDC}(470 \mathrm{~g} ; 2.4 \mathrm{mmol})$ were reacted in $\mathrm{CH}_{2} \mathrm{Cl}_{2}$ as described in the general procedure. The crude product was purified using Heptane:AcOEt as eluent. Pure compound was isolated as a white powder (500 mg; 60\%).

Deprotection: $N$-Boc-L-Phe-L-Tyr-OMe $(200 \mathrm{mg}$; $0.45 \mathrm{mmol})$ was dissolved in $\mathrm{MeOH}$ and $\mathrm{HCl} 4 \mathrm{M}$ in dioxane $(2.3 \mathrm{~mL} ; 9.0 \mathrm{mmol})$ as described in the general procedure. The mixture was concentrated in vacuo to give pure deprotected compound $(0.150 \mathrm{mg}$; quant.).

Cyclisation: deprotected compound L-Phe-L-Tyr-OMe (102 mg; $0.30 \mathrm{mmol})$ and triethylamine $(105 \mu \mathrm{L}$; $0.72 \mathrm{mmol})$ were reacted as described in the general procedure. Pure 7 was isolated as white powder $(0.051$ g; 51\%). White solid. [ $\alpha]^{25}{ }_{\mathrm{D}}-44$ (c 0.3, AcOH); ${ }^{1} \mathrm{H}$ NMR $\left(500 \mathrm{MHz}, \mathrm{DMSO}-d_{6}\right) \delta_{\mathrm{H}} 7.27(2 \mathrm{H}, \mathrm{t}, J=7.4 \mathrm{~Hz}$, H-10), 7.04 (2H, d, J=7.3 Hz, H-9), 7.02 (1H, t, J=7.3 Hz, H-11), 6.84 (2H, d, J=8.2 Hz, H-14), 6.67 (2H, $\mathrm{d}, J=8.4 \mathrm{~Hz}, \mathrm{H}-15), 3.94(1 \mathrm{H}, \mathrm{dd}, J=6.7$ and $5.1 \mathrm{~Hz}, \mathrm{H}-3), 3.89(1 \mathrm{H}, \mathrm{t}, J=4.8 \mathrm{~Hz}, \mathrm{H}-6), 2.58(1 \mathrm{H}, \mathrm{dd}, J=$ 13.7 and $4.9 \mathrm{~Hz}, \mathrm{H}-7 \mathrm{a}), 2.52(1 \mathrm{H}, \mathrm{m}, \mathrm{H}-12 \mathrm{a}), 2.20$ (1H, dd, $J=13.8$ and $6.6 \mathrm{~Hz}, \mathrm{H}-7 \mathrm{~b}), 2.18$ (1H, dd, $J=$ 13.6 and 6.1 Hz, H-12b); ${ }^{13} \mathrm{C}$ NMR (75 MHz, MeOD) $\delta_{\mathrm{C}} 166.2$ (C, C-2), 166.1 (C, C-5), 156.1 (C, C-16), 136.6 (C, C-8), 130.8 (CH, C-14), 129.7 (CH, C-9), 128.2 (CH, C-10), 128.1 (C, C-13), 126.4114 .9 (CH, C-15), (CH, C-11), 55.7 (CH, C-6), 55.4 (CH, C-3), $38.8\left(\mathrm{CH}_{2}, \mathrm{C}-7\right), 38.5\left(\mathrm{CH}_{2}, \mathrm{C}-12\right)$; HRMS-ESI ${ }^{+} \mathrm{m} / z$ 333.1208 (calcd for $\mathrm{C}_{18} \mathrm{H}_{18} \mathrm{~N}_{2} \mathrm{O}_{3} \mathrm{Na}, 333.1215, \Delta-2.1 \mathrm{ppm}$ ).

\section{ACKNOWLEDGEMENTS}

This work is part of the C2 component of the CRISP (Coral Reef Initiative in the South Pacific) project and granted by the Agence Française de Développement (grant CZZ 3012.01 T, AFD). We thank the Fiji Islands government for allowing us to collect in their country and K. Feussner (IAS, University of the South Pacific in Suva, Fiji) for his assistance in this project.

\section{REFERENCES}

1. (a) Y. C. Park, S. P. Gunasekera, J. V. Lopez, P. J. McCarthy, and A. E. Wright, J. Nat. Prod., 2006, 69, 580; (b) G. S. Jayatilake, M. P. Thornton, A. C. Leonard, J. E. Griwade, and B. J. Baker, J. Nat. Prod., 
1996, 59, 293; (c) M. Ginz and U. H. Engelhardt, Eur. Food Res. Technol., 2001, 213, 8.

2. (a) T. Stark, S. Bareuther, and T. Hofmann, J. Agric. Food Chem., 2006, 54, 5530; (b) C. B. Cui, H. Kakeya, and H. Osada, Tetrahedron, 1996, 52, 12651; (c) K. Kanoh, S. Kohno, J. Katada, I. Uno, and Y. Hayashi, Bioorg. Med. Chem., 1999, 7, 1451; (d) F. Fdhila, V. Vazquez, J. L. Sanchez, and R. Riguera, J. Nat. Prod., 2003, 66, 1299; (e) R. Musetti, R. Polizzotto, A. Vecchione, S. Borselli, L. Zulini, M. D’Ambrosio, L. Sanita di toppi, and I. Petrot, Micron, 2007, 38, 643; (f) M. Sjgren, U. Gransson, A. L. Johnson, M. Dahlstrm, R. Anderson, J. Bergman, P. R. Jonsson, and L. Bohlin, J. Nat. Prod., 2004, 67, 368; (g) X. Li, S. Dobretsov, Y. Xu, X. Xiao, O. S. Hung, and P. Y. Qian, Biofouling, 2006, 22, 201; (h) P. Klausmeyer, O. M. Z. Howard, S. M. Shipley, and T. G. McCloud, J. Nat. Prod., 2009, 72, 1369.

3. C. Cornacchia, I. Cacciatore, L. Baldassarre, A. Mollica, F. Feliciani, and F. Pinnen, Mini-Rev. Med. Chem., 2012, 12, 2.

4. (a) G. Wu, J. Liu, L. Bi, M. Zhao, C. Wang, M. Baudy-Floc'h, J. Ju, and S. Peng, Tetrahedron, 2007, 63, 5510; (b) P. W. Baures, W. H. Ojala, W. J. Costain, M. C. Ott, A. Pradhan, W. B. Gleason, R. K. Mishra, and R. L. Johnson, J. Med. Chem., 1997, 40, 3594; (c) M. E. Alvarez, D. R. Houck, C. B. White, J. E. Brownell, M. A. Borko, C. A. Rodger, M. B. Stawicki, H. H. Sun, A. M. Gillum, and R. Cooper, J. Antibiot., 1994, 47, 1195; (d) A. D. Borthwick, D. E. Davies, A. M. Exall, R. J. D. Hatley, J. A. Hughes, W. R. Irving, D. G. Livermore, S. L. Sollis, F. Nerozzi, K. L. Valko, M. J. Allen, M. Perren, S. S. Shabbir, P. M. Woollard, and M. A. Price, J. Med. Chem., 2006, 49, 4159.

5. R. Ortiz-Castroa, C. Díaz-Péreza, M. Martínez-Trujillob, R. E. del Rio, J. Campos-Garcíaa, and J. López-Bucioa, Proc. Natl. Acad. Sci. USA, 2011, 108, 7253.

6. (a) K. E. Klose, J. Bacteriol., 2006, 188, 2025; (b) M. W. Taylor, R. Radax, D. Steger, and M. Wagner, Microbiol. Mol. Biol. Rev., 2007, 71, 295.

7. X. Li, K. H. Hopmann, J. Hudecovaa, J. Isaksson, J. Novotnaa, W. Stensen, V. Andrushchenko, M. Urbanova, J.-S. Svendsen, P. Bour, and K. Ruud, J. Phys. Chem., 2013, 117, 1721.

8. C. W. J. Chang, A. Patra, J. A. Baker, and P. J. Scheuer, J. Am. Chem. Soc., 1987, 109, 6119.

9. M. Tullberg, M. Grotli, and K. Juthman, Tetrahedron, 2006, 62, 7484.

10. T. Stark and T. Hofmann, J. Agric. Food Chem., 2005, 53, 7222.

11. S. D. Bull, S. G. Davies, A. C. Garner, and M. D. O’Shea, J. Chem. Soc., Perkin Trans., 1, 2001, 3281 .

12. (a) J. Xing, Z. Yang, B. Lv, and L. Xiang, Rapid Commun. Mass Spectrom., 2008, 22, 1415; (b) Y. Zeng, Q. Li, R. P. Hanzlika, and J. Aubé, Bioorg. Med. Chem. Lett., 2005, 15, 3034.

13. (a) Y. Lin, X. Wu, Z. Deng, J. Wang, S. Zhou, L. L. P. Vrijmoed, and E. B. G. Jones, Phytochemistry, 
2002, 59, 469; (b) A. Trigos, S. Reyna, and D. Graillet, Rev. Soc. Quim. Mex., 1995, 39, 184.

14. K. Blaha and I. Fric, Coll. Czech. Chem. Commum., 1970, 35, 619.

15. D. E. Nitecki, B. Halpern, and J. W. Westley, J. Org. Chem., 1968, 33, 864.

16. T. M. Hooker, Jr., P. M. Bayley, W. Radding, and J. A. Schellman, Biopolymers, 1971, 10, 1973.

17. For $[\alpha]_{\mathrm{D}}-43.3$ (c 0.27, DMSO), see A. Lopez-Cobenas, P. Cledera, J. D. Sanchez, P. Lopez-Alvarado, M. T. Ramos, C. Avendano, and J. C. Menendez, Synthesis, 2005, 3412.

18. For $[\alpha]_{\mathrm{D}}-64$ (c 0.2, AcOH), see M. Tullberg, K. Luthman, and M. Grotli, J. Comb. Chem., 2006, 8, 915.

19. For $[\alpha]_{D}-66$ (c 0.28, DMSO), see L. Perez-Picaso, J. Escalante, H. F. Olivo, and M. Y. Rios, Molecules, 2009, 14, 2836.

20. W. Radding, B. Donzel, N. Ueyama, and M. Goodman, J. Am. Chem. Soc., 1980, 102, 5999.

21. T. M. Hooker, Jr., P. M. Bayley, W. Radding, and J. A. Schellman, Biopolymers, 1974, 13, 549.

22. M. Tanihara, T. Hiza, Y. Imanishi, and T. Higashimura, Bull. Chem. Soc. Jpn., 1983, 56, 1155.

23. S. Egusa, J. Takagi, M. Sisido, and Y. Imanishi, Bull. Chem. Soc. Jpn., 1986, 59, 2195. 